\title{
Nanometer-Sized Amino Acids for the Synthesis of Nanometer- Scale Water-Soluble Molecular Rods of Precise Length
}

\author{
Chris M. Gothard, Nosheen A. Rao, and James S. Nowick ${ }^{\star}$ \\ Department of Chemistry, University of California, Irvine, Irvine, California 92697-2025.
}

\section{Abstract}

This paper introduces the unnatural amino acid $\mathrm{Abc}^{2 \mathrm{~K}}$ as a nanometer-length building block for the creation of water-soluble molecular rods of exceptional size. $\mathrm{Abc}^{2 \mathrm{~K}}$ is a water-soluble variant of the unnatural amino acid 4'-amino-[1,1'-biphenyl]-4-carboxylic acid (Abc) with lysinelike propyloxyammonium side chains at the 2- and 5-positions. The protected building block Fmoc-

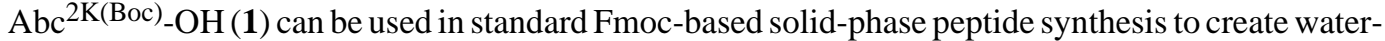
soluble rodlike peptides in nanometer unit lengths up to at least ten nanometers. Oligomers up to and including the decamer were easily prepared on a Rink amide resin. These peptides are easy to purify and characterize by standard reverse-phase HPLC, ${ }^{1} \mathrm{H}$ NMR, and ESI-MS techniques. The $\mathrm{Abc}^{2 \mathrm{~K}}$ amino acid can be combined with various standard amino acids to provide well behaved hybrid and biologically relevant peptides. Building block $\mathbf{1}$ is efficiently prepared on a multigram scale from commercially available starting materials by way of the Suzuki cross-coupling reaction. Molecular modeling studies of $\mathrm{Abc}^{2 \mathrm{~K}}$ oligomers show only minor effects from torsional and bending motions and support a model in which the oligomers are relatively straight and rigid. Fluorescence resonance energy transfer (FRET) studies are consistent with a model in which the $\mathrm{Abc}^{2 \mathrm{~K}}$ oligomers behave as rigid rods with a length of $1.0 \mathrm{~nm}$ per monomer unit.

This paper introduces the unnatural amino acid $\mathrm{Abc}^{2 \mathrm{~K}}$ as a nanometer-length building block for the creation of water-soluble molecular rods in nanometer unit lengths up to at least ten nanometers. Over the past two decades, molecular rods have been developed that can be assembled in precise constitution and length from individual building blocks. ${ }^{1-4}$ Many of these oligomers, such as staffanes and oligo( $p$-phenylene ethynylene)s, require carbon-carbon bond formation for their synthesis and are designed to be soluble in organic solvents. ${ }^{1}$ Nucleic acids provide one attractive approach to water-soluble oligomers and have been used as rodlike components in a variety of architectures. ${ }^{2}$ Peptides and peptide derivatives provide a particularly attractive approach, both because of their biological compatibility and relevance, and because of their ease of assembly through widely available peptide synthesis technologies. ${ }^{3}$ Here, we introduce water-soluble rodlike peptides of exceptional size that are constructed from a 1.0-nm long $\theta$-amino acid. These $\theta$-peptides are easy to assemble and purify with standard peptide synthesis and purification technologies and can be combined with biologically relevant peptides. 

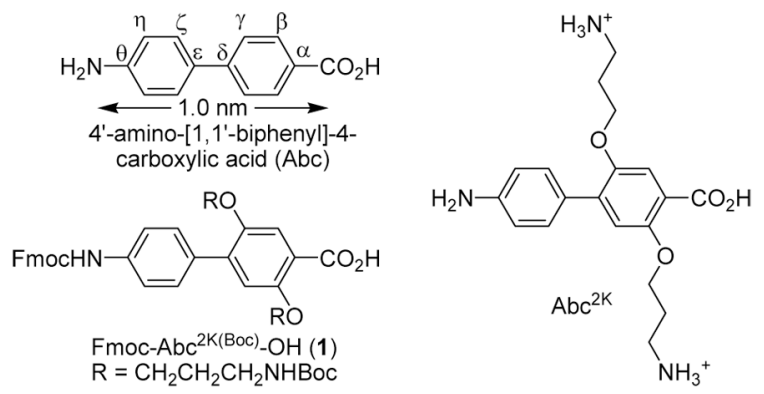

We designed $\mathrm{Abc}^{2 \mathrm{~K}}$ as a water-soluble variant of the unnatural amino acid 4'-amino-[1,1'biphenyl]-4-carboxylic acid (Abc) with lysinelike propyloxyammonium side chains at the 2and 5-positions. ${ }^{5}$ The amino acid $\mathrm{Abc}^{2 \mathrm{~K}}$ is readily prepared as building block $\mathbf{1}$, with Fmoc protection of the aniline main chain and Boc protection of the side chains, to be compatible with standard Fmoc-based solid-phase synthesis. Molecular modeling studies of $\mathrm{Abc}^{2 \mathrm{~K}}$ oligomers show only minor effects from torsional and bending motions and support a model in which the oligomers are relatively straight and rigid. Monte Carlo-stochastic dynamics (MC/ $\mathrm{SD})$ studies of the decamer $\mathrm{H}-\left(\mathrm{Abc}^{2 \mathrm{~K}}\right)_{10}-\mathrm{OH}$ in MacroModel with the AMBER* force field and GB/SA water solvation at $300 \mathrm{~K}$ show an average length of $10.1 \mathrm{~nm}$ with $0.5 \mathrm{~nm}$ standard deviation. Only if unstable cis-amide linkages are introduced does substantial bending of the rods occur. Chart 1 provides a molecular model of the decamer $\mathrm{H}-\left(\mathrm{Abc}^{2 \mathrm{~K}}\right)_{10}-\mathrm{OH}$.

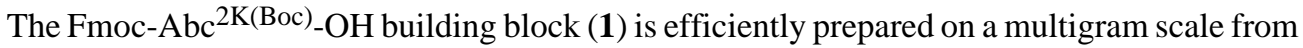
commercially available 1,4-dibromo-2,5-dimethoxybenzene (2). Generation of a Grignard reagent from 2 followed by reaction with dry ice and acidic aqueous workup affords 4bromo-2,5-dimethoxybenzoic acid (3). Cleavage of the methyl ether groups with aqueous $\mathrm{HBr}$ in $\mathrm{AcOH}$ provides 4-bromo-2,5-dihydroxybenzoic acid (4). Protection of the acid group as the phenacyl ester generates ester 5. Introduction of the Boc-3-aminopropoxy " $\mathrm{K}(\mathrm{Boc})$ " side chains by Williamson ether synthesis forms diether $\mathbf{6}$. Suzuki cross-coupling with 4-(4,4,5,5tetramethyl-1,3,2-dioxaborolan-2-yl)aniline (6a) using 3-5 mol\% $\mathrm{PdCl}_{2}(\mathrm{dppf}) \cdot \mathrm{CH}_{2} \mathrm{Cl}_{2}$ gives

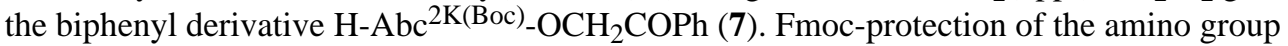

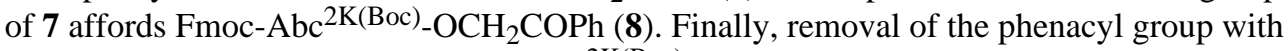

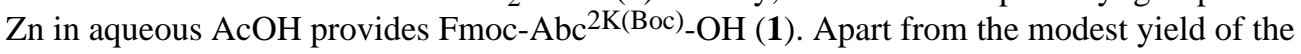
Grignard reaction, these reactions afford $76-95 \%$ yields and easily allow he preparation of 1 in ca. five-gram batches.

Fmoc-Abc ${ }^{2 \mathrm{~K}(\mathrm{Boc})}$-OH (1) can be used like an ordinary Fmoc-protected amino acid in solidphase peptide synthesis. Oligomers up to and including the decamer (9a-9i) were easily prepared on Rink amide resin and purified by reverse-phase HPLC (RP-HPLC). Coupling reactions were typically performed with 3 equivalents of 1 and 12-hr coupling times. Either HCTU and 2,4,6-collidine or diisopropylcarbodiimide and HOAt were used as coupling agents, with the former eventually being found preferable. The oligomers have good water solubility and are readily characterized by standard analytical techniques, such as RP-HPLC, ESI-MS, and ${ }^{1} \mathrm{H}$ NMR spectroscopy in $\mathrm{D}_{2} \mathrm{O}$ solution. Figure 1 illustrates these data for hexamer $9 f$. The ${ }^{1} \mathrm{H}$ NMR spectra of the oligomers are sharp at low concentrations but broaden at higher concentrations, suggesting that little or no aggregation occurs at tenth-millimolar concentrations but that self-association occurs at higher concentrations.

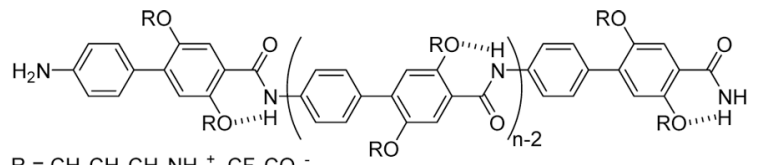

9a $n=1 ; 9 b n=2 ; 9 c n=3 ; 9 d n=4 ; 9 e n=5 ; 9 f n=6 ; 9 g ~ n=7 ; 9 h n=8 ; 9 i n=10$ 
Fluorescence resonance energy transfer (FRET) studies support a model in which the $\mathrm{Abc}^{2 \mathrm{~K}}$ oligomers behave as rigid rods with a length of $1.0 \mathrm{~nm}$ per monomer unit (Figure 2). ${ }^{3 \text { aef, } 6}$ For these studies, we designed a homologous series of oligomers containing the FRET donor and acceptor groups EDANS and Dabcyl linked to the amino acids Glu and Lys and separated by 1-10 Abc ${ }^{2 \mathrm{~K}}$ units [10a-10j, Ac-Lys-Lys-Glu(EDANS)-( $\left(\mathrm{Abc}^{2 \mathrm{~K}}\right)_{\mathrm{n}}$-Lys(Dabcyl)-Lys-Lys$\left.\mathrm{NH}_{2}, \mathrm{n}=1-10\right]{ }^{7}$ We incorporated flanking Lys residues to enhance solubility and reduce aggregation, which proved to be problematic with the hydrophobic EDANS and Dabcyl groups. ${ }^{8}$ FRET studies were performed in 50\% aqueous DMSO (to minimize aggregation of the longer oligomers) with $335 \mathrm{~nm}$ excitation and 400-600 $\mathrm{nm}$ detection. The oligomers exhibit increasing fluorescence with increasing length through the 8-mer 10h, with the largest increases occurring between the 4-mer (10d), 5-mer (10e), and 6-mer (10f). The 9-mer (10i) and 10-mer (10j) exhibit slight decreases and blue-shifting of the fluorescence.

The observed dependence of fluorescence on oligomer length is reasonably consistent with that predicted by the Förster equation [energy transfer efficiency $\left.=1 /\left(1+\mathrm{R}^{6} / \mathrm{R}_{0}{ }^{6}\right)\right] .{ }^{6}$ For the EDANS-Dabcyl pair, the Förster radius $\left(R_{0}\right)$ is $3.3 \mathrm{~nm}$. If each $A b c^{2 K}$ unit provides $1 \mathrm{~nm}$ separation (R) between the EDANS and Dabcyl groups, relatively little fluorescence is predicted for the 1- and 2-mers, substantially increasing fluorescence is predicted for the 3-, 4- and 5-mers, and nearly complete fluorescence is predicted for the 5- to 10-mers. The discrepancy between the predicted and observed fluorescence is consistent with the flexibility of the Glu and Lys tethers (ca. $1 \mathrm{~nm}$ ) and is comparable to variations observed in a related system with a polyproline spacer. ${ }^{3 \mathrm{f}}$ The slight decreasing fluorescence and blue-shifting of the 9-mer and 10-mer may reflect slight aggregation of these compounds.

The $A \mathrm{Ac}^{2 \mathrm{~K}}$ amino acid can be combined with other amino acids using standard Fmoc-based peptide synthesis techniques to give well-behaved hybrid peptides. To demonstrate the ease of synthesizing and handling peptides containing both $\alpha$-amino acids and $\mathrm{Abc}^{2 \mathrm{~K}}$, we synthesized peptide 11, which contains two RGD units separated by a two-nanometer spacer composed of two $\mathrm{Abc}^{2 \mathrm{~K}}$ units. RP-HPLC analysis showed the crude peptide to be $79 \%$ pure, and purification proceeded smoothly by standard RP-HPLC techniques. The peptide is water soluble and easy to characterize by ESI-MS and ${ }^{1} \mathrm{H}$ NMR spectroscopy. We anticipate that the size, water solubility, and ease of incorporation into peptides will make $\mathrm{Abc}^{2 \mathrm{~K}}$ attractive as a rigid linker in various biologically relevant applications. $1 \mathrm{f}, 3 \mathrm{c}, 9$

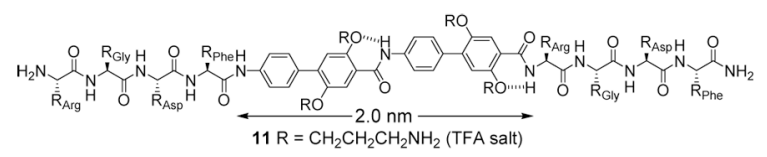

In conclusion, $\mathrm{Abc}^{2 \mathrm{~K}}$ oligomers constitute a new class of water-soluble molecular rods that can be synthesized in precise and defined lengths up to at least $10 \mathrm{~nm}$ in 1-nm increments. The Fmoc-Adc ${ }^{2 \mathrm{~K}(\mathrm{Boc})}$-OH building block is compatible with standard solid-phase peptide synthesis techniques, and the resulting peptides are water soluble and compatible with analytical and purification techniques that are standard for peptides. The ease of assembly and handling of the $\mathrm{Abc}^{2 \mathrm{~K}}$ nanometer-scale molecular rods should permit researchers who are not highly skilled in organic chemistry to use these new architectural elements in areas such as nanotechnology, materials science, and cell biology.

\section{Supplementary Material}

Refer to Web version on PubMed Central for supplementary material. 


\section{Acknowledgement}

We thank the NIH (GM-49076) and ACS-PRF (38986-AC1) for financial support. C. M. G thanks the UCI Institute for Brain Aging and Dementia for training grant support (NIA-5T32AG00096). N. A. R. thanks the Pakistan Higher Education Commission for fellowship support.

\section{References}

1. (a) Tour JM. Chem. Rev 1996;96:537-553. [PubMed: 11848764] (b) Schwab PFH, Levin MD, Michl J. Chem. Rev 1999;99:1863-1933. [PubMed: 11849014] (c) Levin MD, Kaszynski P, Michl J. Chem. Rev 2000;100:169-234. [PubMed: 11749237] (d) Tour JM. Acc. Chem. Res 2000;33:791-804. [PubMed: 11087316] (e) Schwab PFH, Smith JR, Michl J. Chem. Rev 2005;105:1197-1279. [PubMed: 15826013] (f) Sakai N, Mareda J, Matile S. Acc. Chem. Res 2005;38:79-87. [PubMed: 15709727]

2. (a) Seeman NC. Angew. Chem., Int. Ed. Engl 1998;37:3220-3238. (b) Chworos A, Severcan I, Koyfman AY, Weinkam P, Oroudjev E, Hansma HG, Jaeger L. Science 2004;306:2068-2072. [PubMed: 15604402] (c) Rothemund PWK. Nature 2006;440:297-302. [PubMed: 16541064]

3. (a) Stryer L, Haugland RP. Proc. Natl. Acad. Sci. U.S.A 1967;58:719-726. [PubMed: 5233469] (b) Cheng RP, Gellman SH, DeGrado WF. Chem. Rev 2001;101:3219-3232. [PubMed: 11710070] (c) Arora PS, Ansari AZ, Best TP, Ptashne M, Dervan PB. J. Am. Chem. Soc 2002;124:13067-13071. [PubMed: 12405833] (d) Levins CG, Schafmeister CE. J. Am. Chem. Soc 2003;125:4702-4703. [PubMed: 12696876] (e) Levins CG, Schafmeister CE. J. Org. Chem 2005;70:9002-9008. [PubMed: 16238339] (f) Schuler B, Lipman EA, Steinbach PJ, Kumke M, Eaton WA. Proc. Natl. Acad. Sci. U.S.A 2005;102:2754-2759. [PubMed: 15699337] (g) König HM, Gorelik T, Kolb U, Kilbinger AFM. J. Am. Chem. Soc 2007;129:704-708. [PubMed: 17227034]

4. Semetey V, Moustakas D, Whitesides GM. Angew. Chem., Int. Ed 2006;45:588-591.

5. Neustadt BR, Smith EM, Lindo N, Nechuta T, Bronnenkant A, Wu A, Armstrong L, Kumar C. Bioorg. Med. Chem. Lett 1998;8:2395-2398. [PubMed: 9873548]

6. Selvin PR. Methods Enzymol 1995;246:300-334. [PubMed: 7752929]

7. Wang GT, Krafft GA. Bioorg. Med. Chem. Lett 1992;2:1665-1668.

8. Richardson PL. Abbott Laboratories. Personal communication. 2006

9. (a) Strong LE, Kiessling LL. J. Am. Chem. Soc 1999;121:6193-6196. (b) Krishnamurthy VM, Semetey V, Bracher PJ, Shen N, Whitesides GM. J. Am. Chem. Soc 2007;129:1312-1320. [PubMed: 17263415] 

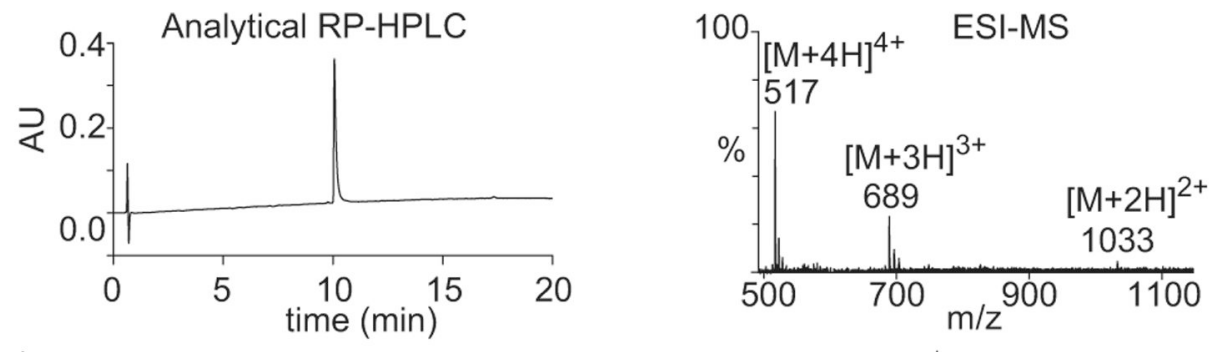

${ }^{1} \mathrm{H}$ NMR (500 MHz, $\left.\mathrm{D}_{2} \mathrm{O}, 0.3 \mathrm{mM}\right)$

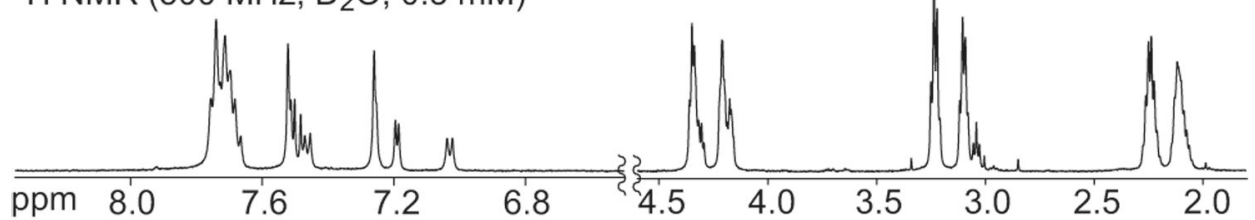

Figure 1.

Characterization data for the $A b c^{2 \mathrm{~K}}$ hexamer $\mathrm{H}-\left(\mathrm{Abc}^{2 \mathrm{~K}}\right)_{6}-\mathrm{NH}_{2}(\mathbf{9 f})$ : analytical RP-HPLC, ESIMS, and ${ }^{1} \mathrm{H}$ NMR spectroscopy. 


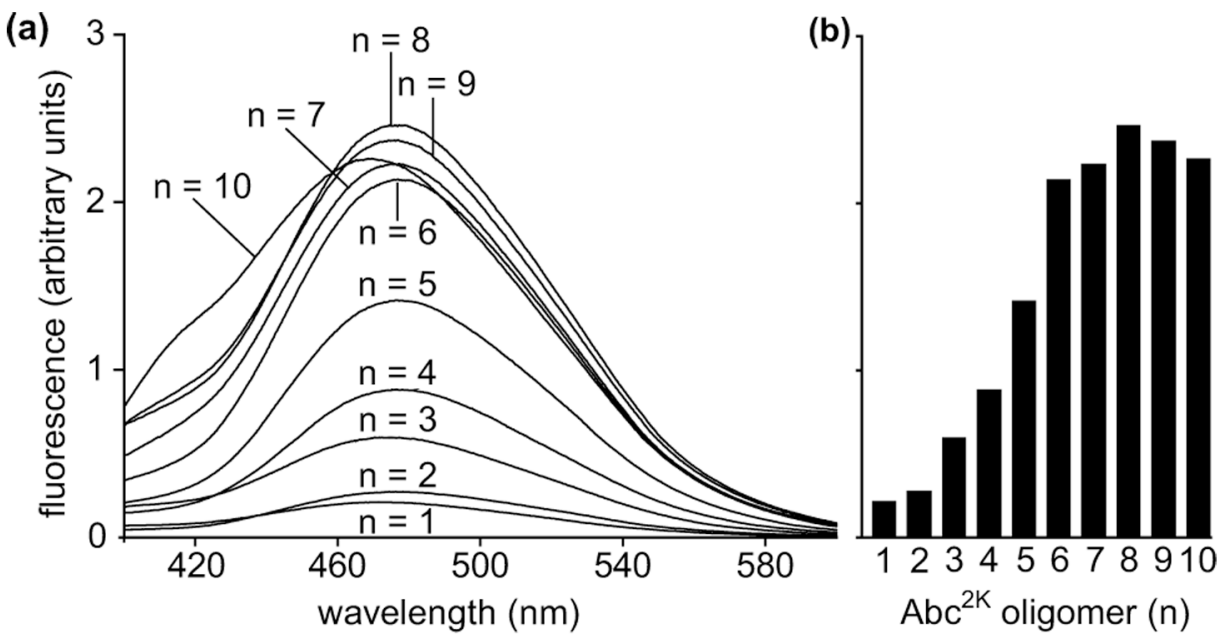

Figure 2.

FRET study of peptides 10a-10j. (a) Fluorescence emission spectra of $1.75 \mu \mathrm{M}$ solutions of the peptides in 50\% aqueous DMSO solution with $335 \mathrm{~nm}$ excitation. (b) Fluorescence intensity at $\lambda_{\max }$. 
<smiles>COc1cc(Br)c(OC)cc1Br</smiles>

2<smiles>[R]Oc1cc(C([R])O[R])c([R])cc1Br</smiles>

1. $6 \mathrm{a}, \mathrm{K}_{2} \mathrm{CO}_{3}$, $\mathrm{PdCl}_{2}$ (dppf) $\bullet \mathrm{CH}_{2} \mathrm{Cl}_{2}$ tolueneDMF- $\mathrm{H}_{2} \mathrm{O}(76 \%)$

2. $\mathrm{Fmoc}-\mathrm{Cl}$, pyridine $\mathrm{CH}_{2} \mathrm{Cl}_{2}(95 \%)$

$4 \mathrm{R}_{1}=\mathrm{H}, \mathrm{R}_{2}=\mathrm{H}$

$5 \mathrm{R}_{1}=\mathrm{H}, \mathrm{R}_{2}=\mathrm{CH}_{2} \mathrm{COPh}$

$6 \mathrm{R}_{1}=\left(\mathrm{CH}_{2}\right)_{3} \mathrm{NHBOC}, \mathrm{R}_{2}=\mathrm{CH}_{2} \mathrm{COPh}$

Scheme 1.

Synthesis of Fmoc-Abc ${ }^{2 \mathrm{~K}(\mathrm{Boc})}-\mathrm{OH}(\mathbf{1})$<smiles>COc1cc(C(=O)O)c(OC)cc1Br</smiles>

1. $\mathrm{HBr}$

$\mathrm{AcOH}-\mathrm{H}_{2} \mathrm{O}(92 \%)$

2. $\mathrm{BrCH}_{2} \mathrm{COC}_{6} \mathrm{H}_{6}, \mathrm{KF}$ DMF $(80 \%)$

3. $\mathrm{Br}\left(\mathrm{CH}_{2}\right)_{3} \mathrm{NHBoc}, \mathrm{K}_{2} \mathrm{CO}_{3}$ DMF $(77 \%)$

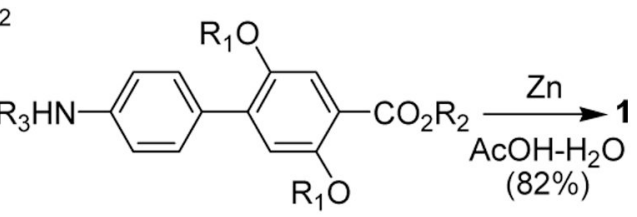

$7 \mathrm{R}_{1}=\left(\mathrm{CH}_{2}\right)_{3} \mathrm{NHBoc}, \mathrm{R}_{2}=\mathrm{CH}_{2} \mathrm{COPh}, \mathrm{R}_{3}=\mathrm{H}$

$8 \mathrm{R}_{1}=\left(\mathrm{CH}_{2}\right)_{3} \mathrm{NHBoc}, \mathrm{R}_{2}=\mathrm{CH}_{2} \mathrm{COPh}, \mathrm{R}_{3}=\mathrm{Fmoc}$ 


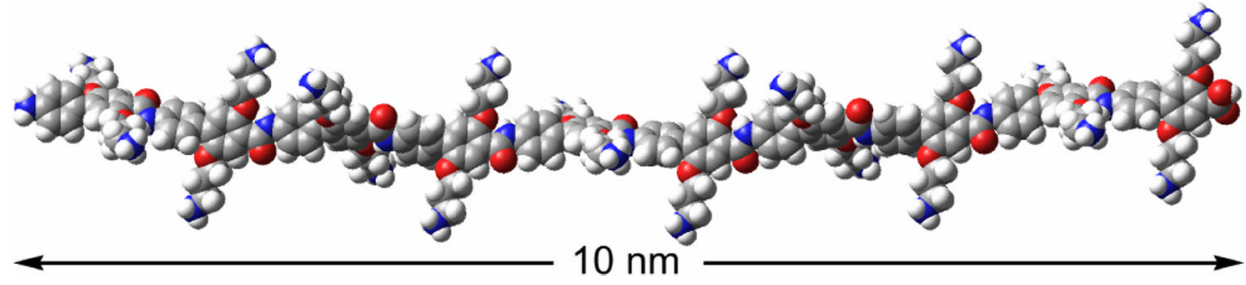

Chart 1.

Molecular Model of $\mathrm{Abc}^{2 \mathrm{~K}}$ Decamer H- $\left(\mathrm{Abc}^{2 \mathrm{~K}}\right)_{10}-\mathrm{OH}$ 